Олександр Васильєв,

ORCID ID 0000-0001-8020-4721

Олег Заболотний,

кандидат військових наук, доцент

ORCID ID 0000-0001-8020-4721

Андрій Зельницький,

кандидат педагогічних наук, професор

ORCID ID 0000-0002-3910-7329

Володимир Оліферук

ORCID ID 0000-0002-0722-7561

Надія Шабатіна

ORCID ID 0000-0002-5066-9517

Національний університет оборони України

імені Івана Черняховського

DOI 10.33099/2617-1775/2019-01/70-81

\title{
МОДЕРНІЗАЦІЯ СИСТЕМИ ВІЙСЬКОВОЇ ОСВІТИ УКРАЇНИ ТА ФОРМУВАННЯ ЗАГАЛЬНОГО ОБРИСУ ОФЦЕРА МАЙБУТНЬОГО: РЕАЛІї І ПЕРСПЕКТИВИ
}

У статті розглянуто сучасний стан і перспективи модернізації освітньої галузі та системи військової освіти України в умовах глобалізачії, переходу до інформаційнотехнологічного суспільства, утвердження пріоритетів сталого розвитку та інших викликів сучасної иивілізації, а також зроблено спробу сформувати обрис офіцера майбутнього $з$ урахуванням начіонального досвіду та досвіду, накопиченого в державах-членах НАТО.

Ключові слова: система військової освіти; гарантування якості освіти; модернізація освіти; компетентність; обрис офічера майбутнього; євроінтеграційні процеси; парадигма освіти.

Постановка проблеми. Вища освіти в Україні перебуває під впливом загальносвітових тенденцій, пов'язаних з глобалізацією, зростанням обсягу інформації та науково-технічного знання, диверсифікацією потреб держави у висококваліфікованих фахівцях. Сучасна система української військової освіти інтегрована 3 державною системою освіти i функціонує на засадах єдиної законодавчої та нормативно-правової бази. Головним завданням системи військової освіти (СВО) є формування кадрового потенціалу Збройних Сил України (ЗС України), створення необхідних передумов для гарантованого комплектування 3С України особовим складом, спроможним ефективно виконувати службові обов'язки за посадовим призначенням в умовах мирного, воєнного часу та в особливий період, що потребує певної модернізації СВО та пошуку нових парадигм. При цьому важливо, щоб динаміка розвитку військової освітньої системи відповідала як найкращим світовим стандартам, так і була адекватною вітчизняним соціокультурним особливостям, відтворювала передовий вітчизняний досвід військової освітньої діяльності.

У контексті модернізації військової освіти нагальними постають проблеми, пов'язані зі створенням універсальної вузівської освітньої інфраструктури; розвитком нових організаційно-управлінських структур; співвідношенням 
освіти 3 соціокультурними особливостями державної освітньої політики; створенням системи безперервної, багаторівневої та багатоступеневої професійної підготовки; розробленням загальнотеоретичних підходів до формування обрису офіцера майбутнього. Усе це має відбуватися на основі базових цінностей і норм розвитку сучасного українського суспільства, тобто в межах державної освітньої політики з її ціннісно-нормативними імперативами $[1 ; 2]$.

Аналіз останніх досліджень і публікацій. Сучасне педагогічне бачення освітніх проблем значною мірою грунтується на досягненнях педагогічної теорії (В. Кремень, Г. Балл, І. Бех, С. Гончаренко, М. Гриньова, А. Іванченко, Н. Кузьміна, В. Моляко, А. Реан, В. Рибалка, А. Сбруєва, Г. Селевко, С. Сисоєва, М. Солдатенков, М. Ярмаченко та ін.). Теоретичні та методологічні аспекти військової освіти, проблеми ii модернізації та якості підготовки військових фахівців, впровадження в освітній процес інноваційних педагогічних технологій та сучасних методів навчання розглядаються у дослідженнях науковців педагогів і психологів вищої військової школи (Ю. Бараш, А. Вітченко, С. Домбровська, М. Нещадим, В. Осьодло, С. Полторак, Ю. Приходько, А. Ромін, І. Руснак, В. Садковий, С. Салкуцан, В. Свистун, В. Телелим, Р. Тимошенко, В. Ягупов та ін.).

Найбільш загальні питання 3 удосконалення військової освіти України викладено у документах оборонного планування: Стратегічному оборонному бюлетені України та Державній програмі розвитку Збройних Сил України на період до 2020 року, а також у Концепції військової кадрової політики у Збройних Силах України, де висвітлено основні завдання чинної системи вищої військової освіти в Україні, в тому числі, у контексті формування загальноєвропейського простору вищої освіти. Розкрито прагматизм впровадження нових підсистем організації навчального процесу у вищих військових навчальних закладах України та військових навчальних підрозділах закладів вищої освіти (ВВНЗ, ВНП ЗВО) відповідно до вимог Болонської декларації. Особливу увагу звернуто на проблеми забезпечення та гарантування якості освіти в Україні відповідно до стандартів НАТО.

Метою статті є спроба сформувати загальний обрис офіцера майбутнього, створити уявлення про його професійні, особистісні, світоглядні, громадянські, психофізіологічні якості та ціннісні орієнтації, виходячи 3 реалій стану вітчизняної системи військової освіти і перспектив щодо ії модернізації.

Методи дослідження: системний аналіз і синтез, індукція та дедукція, порівняння, класифікація, узагальнення та систематизація.

Виклад основного матеріалу. У сучасних умовах розвиток цивілізації визначають стійкі планетарні тенденції, а саме:

посилення ролі військових факторів у вирішенні міжнародних політичних, економічних, етнічних, міжконфесійних та інших конфліктів;

поширення неконтрольованої міграції населення, діяльності екстремістських, терористичних організацій;

стрімке зростання обсягів військово-наукових знань; 
пошук, розроблення й випробування новітніх систем озброєння та військової техніки, принципів системного бойового застосування їх конфліктних регіонах із наслідками й ознаками згубного руйнівного інфраструктурного, соціального, економічного, історико-культурного характеру $[3$, c. 21$]$.

Тобто, йдеться про впливи воєнно-політичних чинників на цивілізаційні процеси, а значить й про відповідне реагування з боку країн світу на подібні виклики, що природно трансформуються у підготовку держав та їх сил оборони до ведення воєн у реальному часі та воєн майбутнього. Дана проблема значно актуалізувалася протягом останнього часу і знайшла своє відображення в наукових публікаціях воєнних експертів i, перш за все, експертів США. Так, у вересні 2017 року в США вийшла книга генерал-майора ВПС США у відставці Роберта Латіффа "Майбутня війна", в якій наголошується на тому, що за останні декілька років у світі зріс інтерес до феномену штучного інтелекту та його використання у військовій сфері. Р. Латіфф описує інноваційні технології: 3D-друк в космосі, робота з базами даних і великими обсягами інформації, космічна розвідка, військова робототехніка, безпілотники, нові матеріали тощо. Автор пише про те, що у сучасних війнах зникло поняття “поле бою”, а 3 “демократизацією” військових технологій розвинені країни втратили монополію на військово-стратегічну перевагу. У ході бойових дій застосовуватимуть штучний інтелект i синтетичну біологію (генно модифікованих солдат). Усі ці технології автор книги досліджує у поєднанні 3 питаннями військової етики. На його думку, війна стане не справою знищення військових підрозділів, а умінням впливати на кожного окремого індивідуума, хоча сьогодні ми сприймаємо всі ці технології як щось ефемерне.

Воєнний експерт США Пол Скарре - ветеран воєн в Іраку та Афганістані, дослідник проблеми використання штучного інтелекту i роботизації у військовій сфері, колишній радник заступника міністра оборони США Боба Уорка - у книзі "Нічия армія: автономна зброя і майбутні війни" досліджує історію створення та використання автономних систем $з$ часів II Світової війни На думку П. Скарре сьогодні десятки країн мають оборонні автономні системи, які поки що працюють під наглядом людини. Найближче майбутнє - гонка наступального автономного озброєння. На допомогу військовим приходять сучасні технології: штучний інтелект, нейронні мережі тощо. Автор також наголошує й на етиці використання автономних систем: “...найбільшою перевагою роботів $є$ те, що в стресових ситуаціях, коли людина не може стабільно функціонувати i приймати рішення, машини залишаються холоднокровними", але виникає безліч етичних питань стосовно делегування рішень щодо знищення цілей автономним системам. Разом з тим, П. Скарре ставить й таке питання - чи можуть США стати лідерами в цій галузі і дозволити часткову автономність роботам на полі бою, чи країна має стримувати свій розвиток, сподіваючись, що інші держави теж утримаються від автоматизації війни? Автор попереджає, що автоматизація дозволяє легше 
розпочати бойові дії та може стати причиною абсолютної жорстокості у майбутніх війнах.

Стосовно оновлення тактики ведення бойових дій підрозділами армії США, то в даному контексті варто дослухатися до думки командуючого Корпусом морської піхоти США Роберта Неллера щодо "розподілених операцій”, в яких війська мають розосереджуватися, щоб уникати високоточних ударів противника. При цьому ставка робиться на сучасно оснащені невеликі підрозділи. Так, кожне піхотне відділення окрім індивідуального озброєння матиме власний міні-квадрокоптер для розвідки обстановки та оператора, який буде ним управляти. В усіх ротних штабах буде свій розвідувальний підрозділ; оператор безпілотного літального апарату (БПЛА) для проведення розвідувальних операцій; спеціаліст з боротьби із БПЛА противника, який буде протистояти розвідувальним діям противника 3 використанням дронів; спеціаліст з логістики, який буде забезпечувати підрозділ усім необхідним. Ідея створення таких підрозділів полягає в підвищенні їхної спроможності та готовності діяти автономно, ефективно, відповідально і більш незалежно від вищого командування, де роль офіцера, особливо тактичної ланки управління, стає вирішальною.

Стійкі тенденції щодо підготовки держав до ведення воєн майбутнього мають знаходити своє віддзеркалення як у процесах модернізації освітньої галузі загалом, так і галузі військової освіти, основним сенсом якої є якісна підготовка військових фахівців нової генерації.

Стосовно модернізації національної освітньої галузі в умовах сучасних глобалізаційних процесів, то, на нашу думку, заслуговують на увагу наукові доробки доктора педагогічних наук, професора О. А. Дубасенюк. У контексті розвитку сучасного педагогічного знання авторка виділяє такі актуальні аспекти модернізації освіти, що характеризуються парадигмальною спрямованістю, а саме: парадигма діалогу культур; міждисциплінарна парадигма; парадигма цілісності; рефлексивна парадигма педагогічної діяльності; ноосферна парадигма; парадигма інноваційного розвитку. Серед наведених основних концептуальних настанов, притаманних даному етапу розвитку науки, культури, найбільший інтерес викликає представлена ноосферна парадигма, що розкриває сутність і зміст переходу освіти до таких принципів:

ноосферно-природовідповідних (біоадекватних);

екологізації (звернення до природних способів сприйняття інформації);

системності (опора на системні дослідження);

гармонізації (використання технологій і методик цілісного сприйняття світу і мислення, занурення тих, хто навчаються, у гармонію світу);

гуманізації (перехід від технократичної до соціокультурної моделі освіти);

інструментальності (здатність використовувати знання, вміння та навички у всіх сферах життя);

особистісно орієнтованої освіти, випереджальної освіти; 
економічності освіти (побудова і проведення технологій і методик, які не перевищують необхідних соціальних витрат та приводять до економії часу, сил, засобів, фінансів);

потенційної інтелектуальної безпеки (виходить із надр цілісної, здорової людини та базується на природовідповідності, самоорганізації інформації, інваріантності, коли робота з природними символами $є$ потенційно безпечною) [4]. Тобто освіта у контексті глобалізаційних тенденцій і сучасних викликів має професійніше готувати людину до життя в інформаційному суспільстві, суспільстві знань та інновацій

Зазначені парадигмальні засади модернізації освітньої галузі України $\epsilon$ методологічним підгрунтям модернізації системи військової освіти (далі CBO). На теперішній час СВО Україні потребує суттєвого оновлення відповідно до визначених законодавством України потреб інтеграції нашої держави в європейський політичний, економічний, безпековий, правовий простори, набуття членства в Європейському Союзі та в Організації Північноатлантичного договору. До того ж, подальший розвиток СВО щільно пов'язаний і з впливом інших чинників: бурхливими змінами в інформатизації суспільства; стрімким розвитком ЗС України та їх кардинальною структурною перебудовою; проведенням операції об'єднаних сил (ООС) на сході України; здійсненням демократичного цивільного контролю над Воєнною організацією України, а також необхідністю підготовки ЗС України до ведення війн майбутнього. Останнє потребує пильної уваги, адже ведення війн майбутнього передбачає підготовку офіцерів майбутнього в модернізованій відповідно до глобалізаційних тенденцій і сучасних викликів системі військової освіти.

Система військової освіти являє собою цілісне утворення, основними структурними компонентами якої $\epsilon$ такі: органи управління військовою освітою; мережа закладів військової освіти (університети, академії, військові інститути, в тому числі у складі цивільних університетів, військові коледжі, факультети і кафедри військової підготовки, а також військові ліцеї та ліцеї 3 посиленою військово-фізичною підготовкою; стандарти освітньої діяльності та стандарти освіти (професійний стандарт); рівні та ступені кваліфікації освіти (галузева рамка кваліфікацій); галузі знань, спеціальності і спеціалізації; освітньо-професійні (освітньо-наукові) програми; учасники освітнього процесу; законодавча та нормативно-правова база [5].

Аналіз нинішнього стану системи військової освіти, а також світових тенденцій та досвіду провідних країн-членів НАТО щодо розвитку освітньої галузі у змінюваному освітньому середовищі засвідчує про наявність низки проблем i стримуючих чинників ефективного функціонування СВО що зумовлені, здебільшого, новими викликами, які постали перед суспільством, державою, ЗС України та СВО і на які потрібно адекватно реагувати.

До основних причин виникнення цих проблем варто віднести такі:

1. Організаційні:

незавершеність розроблення нормативно-правових актів з питань розвитку та функціонування СВО на найближчу перспективу, у тому числі: галузева 
рамка кваліфікацій, професійний стандарт, політика забезпечення i гарантування якості освіти;

несистемний процес прогнозування розвитку СВО на середньострокову перспективу у змінюваному освітньому середовищі в контексті забезпечення національної безпеки України та захисту іiі національних інтересів 3 урахуванням досвіду країн-членів НАТО;

несформованість обрису офіцера майбутнього (офіцер-2030р.) щодо уявлення про його особистісні, професійні, світоглядні, громадянські, психофізіологічні якості та ціннісні орієнтації, як основи для розроблення відповідної компетентнісної моделі, яку потрібно динамічно впроваджувати в освітній процес;

часткова невідповідність існуючої мережі СВО та організаційно-штатних структур їі складових перспективам і динаміці розвитку ЗС України;

недієвий зворотний зв'язок військ (сил) 3 вищими військовими навчальними закладами та військовими навчальними підрозділами закладів вищої освіти (далі - ВВНЗ, ВНП ЗВО);

недієва система відповідальності ВВНЗ, ВНП ЗВО за якість підготовки здобувачів освіти, за реалізацію законодавчо закріплених вимог щодо внутрішнього та зовнішнього забезпечення і гарантування якості освіти та освітньої діяльності;

неоптимальність підходів щодо використання нормативно введених військових і цивільних галузей знань та спеціальностей при плануванні підготовки військових фахівців у ВВНЗ та ВНП 3ВО;

незадовільний рівень проведення військово-професійної орієнтації молоді, національно-патріотичного виховання, військової підготовки в середніх загальноосвітніх навчальних закладах (допризовної підготовки);

низький конкурс на вступ до ВВНЗ, ВНП ЗВО;

низька якість військово-професійного відбору кандидатів до вступу у ВВН3 (військові університети, академіі та інститути), ВНП ЗВО (військові інститути, факультети та кафедри військової підготовки), навчальні центри та військові ліцеї, незадовільний рівень інтелектуальної, психологічної і фізичної підготовленості кандидатів на навчання;

неефективність системи конкурсного відбору осіб-кандидатів на посади педагогічних, науково-педагогічних та наукових працівників ( НПП ).

2. Соціально-економічні:

падіння престижності військової служби та мотивації щодо її проходження серед громадян України;

недостатній рівень соціального і правового захисту військовослужбовців і членів їхніх сімей;

відсутність цілісної, дієвої системи соціально-економічних стимулів за результатами службової діяльності військовослужбовців у військах (силах), та НПП у ВВНЗ, ВНП ЗВО;

нестійкість мотивів певної частини кандидатів на навчання у ВВНЗ, ВНП ЗВО i курсантів старших курсів щодо подальшого проходження ними 
військової служби у ЗС України після завершення навчання або строку дії відповідного контракту;

3.Навчально-методичні, науково-інноваційні:

повільне реагування на сучасні тенденції гуманізації та гуманітаризації військової освіти та на потреби практики щодо розроблення міждисциплінарних курсів навчання та включення в освітній процес нових навчальних дисциплін;

повільне впровадження в педагогічну практику основ професіографічного та компетентнісного підходів у ході проектування освітньої діяльності щодо підготовки здобувачів військової освіти;

неповна відповідність змісту освіти сучасному досвіду бойової та оперативної підготовки військ (сил), їх застосуванню у війнах, локальних конфліктах, антитерористичних і міжнародних операціях з підтримання миру та безпеки;

повільне впровадження в освітній процес сучасних інформаційних, інформаційно-комунікаційних, інтерактивних, особистісно-орієнтованих педагогічних технологій і технологій дистанційного навчання;

невідповідність рівня володіння іноземними мовами здобувачами військової освіти зростаючим вимогами щодо гармонізації стандартів та впровадження процедур НАТО, досягнення взаємосумісності зі збройними силами країн-членів альянсу;

повільне впровадження вимог відповідних стандартів НАТО у діяльність ЗС України та у військову освітню галузь;

недостатня ефективність інтеграції наукової, науково-технічної, інноваційної діяльності з освітнім процесом ВВНЗ, ВНП ЗВО.

4. Матеріально-технічні, фінансово-економічні:

застарілість матеріально-технічної бази (МТБ) закладів військової освіти, недостатня кількість (відсутність) сучасних зразків озброєння та військової техніки (ОВТ), навчально-тренувальних систем, комплексів, лабораторій, центрів моделювання тощо у ВВНЗ, ВНП ЗВО;

недостатнє забезпечення закладів військової освіти фінансовими, матеріально-технічними ресурсами та неефективне використання наявних ресурсів.

Розв'язання зазначених проблем неможливе без глибокої модернізації CBO, що передбачає необхідність проведення таких першочергових заходів:

законодавчого й нормативного врегулювання основних положень підготовки військових фахівців, адаптації нормативно-правової бази Міністерства оборони в галузі військової освіти до вимог законодавства держави 3 урахуванням досвіду проведення антитерористичної операції та операції Об’єднаних сил (АТО, ООС) і передового досвіду країн-членів НАТО;

подалышої оптимізації мережі ВВНЗ, ВНП ЗВО та організаційно-штатних структур закладів військової освіти;

розроблення i впровадження в педагогічну практику політики гарантування якості підготовки офіцерських кадрів; 
приведення змісту освіти у відповідність до сучасних і перспективних завдань Збройних Сил України з максимальним використанням досвіду ООС, АТО та передових методик і сучасних педагогічних технологій підготовки армій країн-членів НАТО, у тому числі - активне впровадження технологій дистанційного навчання;

поліпшення якості підготовки науково-педагогічних кадрів, удосконалення механізму ротації науково-педагогічних працівників;

удосконалення системи відбору та підготовки кандидатів на вступ до ВВНЗ, ВНП ЗВО та ії планомірний розвиток;

формування та укріплення системи професійної підготовки сержантів як важливої сучасної категорії військових кадрів.

У даному контексті щодо ефективного функціонування СВО малодослідженою залишається проблема формування обрису офіцера майбутнього як еталону, до якого необхідно постійно наближатися.

Обрис офіцера майбутнього (офіцера - 2030 р.) є уявленням про його професійні, особистісні, світоглядні, громадянські психофізіологічні якості та ціннісні орієнтації, які формуються та розвиваються в ході освітньої діяльності у ВВНЗ, ВНП ЗВО та вдосконалюються протягом усієї військової служби.

Офіцер майбутнього - це офіцер нової генерації, офіцер-лідер, психологічно стійкий, творча особистість, національно свідомий громадянин України, здатний на високому професійному рівні вирішувати бойові та оперативні завдання в умовах мирного, воєнного часу та в особливий період із застосуванням найскладніших систем ОВТ, ефективно діяти у міжнародних операціях з підтримання миру та безпеки під егідою ООН, співпрацювати зі штабами багатонаціональних сил НАТО.

Виходячи з цього, при формуванні обрису офіцера майбутнього варто враховувати такі характеристики його професії як:

лідерська - за необхідністю бути авторитетним формальним (за посадою) i неформальним (за загальнолюдськими і професійними якостями) лідером, відігравати головну роль в організації спільної діяльності і регулювати взаємовідносини у колективі, вести за собою, приймати відповідальні рішення, впливати на членів військового колективу, досягати поставленої мети;

самовдосконалення - за намаганням постійного наближення показників рівня сформованості професійних, особистісних, світоглядних, громадянських психофізіологічних якостей та ціннісних орієнтацій до показників уявного, змінюваного в часі еталонного образу офіцера ЗС України (компетентнісна модель офіцера майбутнього);

правова - за усвідомленою необхідністю спиратися в професійній діяльності на набуті знання Конституції України, законодавчих актів щодо військової служби, Статутів ЗС України, Військової присяги, гуманітарного права війни;

вербальна - за засобами комунікації з особовим складом в умовах безпосереднього та опосередкованого зв'язку з ним; 
психолого-педагогічна - за сформованістю умінь: згуртовувати підлеглий особовий склад, формувати в нього почуття відповідальності за підтримання себе, техніки та озброєння підрозділу у стані постійної бойової готовності; здійснювати конкретні заходи щодо зміцнення військової дисципліни та правопорядку; прищеплювати особовому складу навички безконфліктного, нерепресивного спілкування, почуття дружби, товариськості, взаємовиручки; психологічно готувати особовий склад до дій в екстремальних умовах; адаптувати молодих воїнів до специфіки військової служби;

індивідуальна - за формою організації діяльності;

самостійна - за способами службової діяльності - без сторонньої допомоги, дріб'язкової опіки з боку керівництва (у межах виконання завдань);

критичного мислення - за усвідомленістю власних розумових дій, усвідомленістю проблеми та суперечностей, що знаходиться в основі проблеми, переконанням в необхідності ії розв'язання, у проведенні оцінки середовища на безпеку, у здатності адекватно діяти в умовах невизначеності, у передбаченні змін і управлінні змінами, у пошуку такого способу зміни обставин, який розв'яже дану суперечність та сприятиме новому баченню майбутнього, у формулюванні мети своїх дій; у діяльності на основі довіри, розуміння та емпатії;

полікомунікативна - за обсягом службової комунікації 3 періодично змінним колом осіб: начальники, підлеглі, колеги, малі і великі групи людей; 3 представниками місцевого населення, органів державної влади, місцевого самоврядування, громадських організацій, військовослужбовцями структурних підрозділів країн-членів НАТО;

інформаційно-комунікативна - за сформованістю умінь: привертати увагу аудиторії, висловлювати власну думку, аргументувати, переконувати, вислуховувати співрозмовника, сприймати іншу точку зору, орієнтуватися в інформаційних потоках, користуватися ПЕОМ, вільно спілкуватися державною мовою та володіти на визначеному рівні (СМР-2) однією 3 іноземних (англійською) мовою;

розумова - за співвідношенням розумового і фізичного навантаження;

творча - така, що в межах виконання завдань не піддається повною мірою алгоритмічному опису;

динамічна - за змінними умовами професійної діяльності;

стресогенна - за особливими умовами виконання службових обов'язків, що пов'язані з впливом стресогенних факторів середовища і діяльності;

морально відповідальна за здоров'я і життя особового складу, збереження матеріальних цінностей [6].

Наведена характеристика професії офіцера 3С України цілком узгоджується 3 досвідом провідних країн-членів НАТО щодо формування обрису офіцера майбутнього, якому мають бути притаманні такі якості:

надавати велике значення духовним цінностям суспільства та бути переконаним у необхідності розвитку власного характеру; 
демонструвати впевненість у собі, чесність, креативність, сміливість, критичне мислення;

брати на себе повну відповідальність за власні рішення у будь-якій швидко мінливій, невизначеній i складній обстановці, швидко пристосовуватися до нових умов;

бути самодисциплінованим, витривалим та сміливим у виконанні обов'язків в звичайних та екстремальних умовах; мати чесне та добровільне бажання поводитися правильно;

бути самовідданим в служінні країні, виду 3С та некорисливо ставитися до підлеглих;

ставити пріоритетами виконання особистих та професійних завдань на високому рівні;

поважати почуття власної гідності кожної людини;

поводитися рішуче, навіть коли існує ймовірний високий ризик;

знати принципи діяльності НАТО, інших країн, вміти створювати ефективні команди (підрозділи та відділи) в оперативних та міжнародних операціях 3 підтримання миру та безпеки, в умовах зміни організаційних структур і технологій [7].

Висновки. Таким чином, у статті представлено загальнотеоретичні підходи до формування обрису офіцера майбутнього як цілісного уявлення щодо його професійних, особистісних, світоглядних, громадянських психофізіологічних якостей та ціннісних орієнтацій, які формуються та розвиваються в СВО (в ході освітньої діяльності у ВВНЗ, ВНП ЗВО) та вдосконалюються протягом усієї військової служби. Подальші дослідження щодо розв'язання зазначеної проблеми мають знайти своє відображення у компетентнісній моделі офіцера майбутнього, що розробляється з урахуванням особливостей їх підготовки у кожному із ВВНЗ, ВНП ВНЗ з реалізацією ними принципу автономності і відповідальності.

\section{ЛIТЕРАТУРА}

1. Полторак С.Т., Методологія державного управління системою вищої військової освіти Теорія та практика державного управління. 2017. N 2. С. 33-38.

2. Полторак С.Т., Трансформація системи військової освіти України на шляху до досягнення стандартів НАТО [Текст] Наука і оборона. 2018. N 2. С. 3-10.

3. Телелим В., Тимошенко Р., Приходько Ю. Військова освіта в системі безпеки та оборони Наука і оборона. 2013. № 4. С. 21-28.

4. Дубасенюк О. Освітні реформи: місія, дійсність, рефлексія Модернізація системи освіти в Україні в умовах сучасних глобалізаційних процесів: монографія / за ред. Василя Кременя, Тадеуша Левовицького, Віктора Огнев'юка, Світлани Сисоєвої. К. : ТОВ “Видавниче підприємство “ЕДЕЛЬВЕЙС”, 2013. С. 253-262.

5. Про вищу освіту: Закон України від 01.07.2014 р. № 1556-VII. Дата оновлення: 28.09.2017. URL: http://zakon4.rada.gov.ua/laws/show/1556-18/page2 (дата звернення: 15.11.2017).

6. Зельницький А., Заболотний О., Приходько Ю. та ін. Моніторинг якості підготовки військових фахівців у вищих військових навчальних закладах та військових навчальних підрозділах вищих навчальних закладів Збройних Сил України : наук.-метод. посіб. / за заг. ред. І. В. Толока. Харків : ХНУПС, 2017. 120 с. 
7. Організаційно-методичні засади адаптації та впровадження інноваційних педагогічних технологій та методик, застосовуваних у військових навчальних закладах провідних країн-членів НАТО, в освітній процес ВВНЗ, ВНП ЗВО МО України: звіт про НДР (заключн.) / Київ. нац. ун-т обор. України ім. І. Черняховського; кер. А.М. Зельницький; викон.: О.А. Заболотний [та ін.]. Шифр теми “Методика НАТО” УДК 378.14.015.62. № держреєстрації 0118U000240. Київ, 2018. 371 с.

\section{REFERENCES}

1. Poltorak, S.T. (2017), Metodolohiia derzhavnoho upravlinnia systemoiu vyshchoi viiskovoi osvity Teoriia ta praktyka derzhavnoho upravlinnia. [Methodology of Public Administration of the Higher Military Education System] N 2., P. 33-38 (in Ukraine).

2. Poltorak S.T., (2018), Transformatsiia systemy viiskovoi osvity Ukrainy na shliakhu do dosiahnennia standartiv NATO [Tekst] Nauka i oborona. [Transformation of Ukraine's Military Education System on the Way to Achieving NATO standards]. N 2. P. 3-10 (in Ukraine).

3. Telelym V., Tymoshenko R., Prykhodko Yu., (2013), Viiskova osvita v systemi bezpeky ta oborony Nauka i oborona [Military Education in the Security and Defense System] № 4. P. 21-28 (in Ukraine).

4. Dubaseniuk O., (2013), Modernizatsiia systemy osvity v Ukraini v umovakh suchasnykh hlobalizatsiinykh protsesiv / Osvitni / za red. Vasylia Kremenia, Tadeusha Levovytskoho, Viktora Ohneviuka, Svitlany Sysoievoi [Modernization of Education System in Ukraine under the Conditions of Modern Globalization Processes], K. : TOV "Vydavnyche pidpryiemstvo "EDELVEIS", P. 253-262 (in Ukraine).

5. Pro vyshchu osvitu : Zakon Ukrainy vid 01.07.2014 r. № 1556-VII. [On Higher Education : Law of Ukraine from 01.07.2014. № 1556-VII] (2017) URL: http://zakon4.rada.gov.ua/laws/show/1556-18/page2. (in Ukraine)

6. Zelnytskyi, A.M. Zabolotnyi, O.A. Prykhodko, Yu. I. ta in. (2017), Monitorynh yakosti pidhotovky viiskovykh fakhivtsiv u vyshchykh viiskovykh navchalnykh zakladakh ta viiskovykh navchalnykh pidrozdilakh vyshchykh navchalnykh zakladiv Zbroinykh Syl Ukrainy : nauk.-metod. posib. / za zah. red. I. V. Toloka [Monitoring of Quality of Training of Military Professionals in Higher Military Educational Institutions and Military Educational Units of Higher Educational Institutions of Armed Forces of Ukraine], 120 p. (in Ukraine).

7. Orhanizatsiino-metodychni zasady adaptatsii ta vprovadzhennia innovatsiinykh pedahohichnykh tekhnolohii ta metodyk, zastosovuvanykh u viiskovykh navchalnykh zakladakh providnykh krain-chleniv NATO, v osvitnii protses VVNZ, VNP ZVO MO Ukrainy: zvit pro NDR (zakliuchn.) / Kyiv. nats. un-t obor. Ukrainy im. I. Cherniakhovskoho; ker. A.M. Zelnytskyi; vykon.: O.A. Zabolotnyi [ta in.]. Shyfr temy "Metodyka NATO” UDK 378.14.015.62. № derzhreiestratsii 0118U000240 [Organizational and methodical principles of adaptation and introduction of innovative pedagogical technologies and techniques used in military educational institutions of leading NATO countries in the educational process of HMEI, the MEU IHE of Ministry of Defense Ukraine: SRW Report (Conclusions)]. Kyiv, 2018. 371 p.

\section{PЕЗЮМЕ}

Александр Васильев, Олег Заболотный, кандидат военных наук, доцент

Андрей Зельницкий, кандидат педагогических наук, профессор

Владимир Олиферук Надежда Шабатина

Национальный университет обороны Украины имени Ивана Черняховского 


\title{
Модернизация системы военного образования Украины и формирование образа офицера будущего: реалии и перспективы
}

B статье рассмотрены современное состояние $u$ перспективы модернизации образовательной сферы и системы военного образования Украины в условиях глобализачии, перехода к информационно-технологическому обществу, установления приоритетов инновационного развития и других вызовов современной ичивилизации, а также сделано попытку сформировать образ офичера будущего с учетом национального опыта и опыта, накопленного в государствах-членах НАТО.

Ключевые слова: система военного образования; гарантия качества образования; модернизация образования; компетентность; образ офицера будущего; євроинтеграционные прочессы; парадигма образования.

\section{SUMMARY}

\author{
Oleksandr Vasyliev \\ Oleg Zabolotnyi, \\ $\mathrm{PhD}$ (Military), assistant professor \\ Andrii Zelnytskyi, \\ $\mathrm{PhD}$ (Pedagogical Sciences), professor \\ Volodymyr Oliferuk \\ Nadia Shabatina \\ National Defence University of Ukraine \\ named after Ivan Cherniakhovskyi, Kyiv
}

\section{Modernization of military education system of Ukraine and formation of officer of the future image: realties and perspectives}

Introduction. The article deals with modern state and prospects for modernization of educational sphere and military education system of Ukraine under conditions of globalization, transition to informational and technological society, endorsement of its priorities, constant development.

Purpose. The purpose of the article is to create a general image officer of the future image, to create an idea of his professional, personal, ideological, civic, psycho-physiological qualities and value orientations, based on the realities of the state of military education national system and the prospects for its modernization.

Methods. The author used system analysis and synthesis, induction and deduction, comparison, classification, generalization and systematization methods.

Results. Due to the modernization of education and eurointegrational processes Professional, personal, philosophical, civic psycho-physiological qualities and value orientations of the officer of the future image are defined in the article.

Originality. Professional, personal, philosophical, civic psycho-physiological qualities and value orientations of the officer of the future image (2030) are presented for the first time .

Conclusion. The article presents the general theoretical approaches to the formation of the officer of the future image as a holistic representation of his professional, personal, philosophical, civic psycho-physiological qualities and value orientations .

Keywords: military education system; education quality guarantee; modernization of education; competence; officer of the future image; euro integrational processes; paradigm of education. 